\title{
GC/MS Analysis of Alkaloids in Galanthus fosteri Baker and Determination of Its Anticholinesterase Activity
}

\author{
Galanthus fosteri Baker'da Alkaloitlerin GC/MS Analizi ve Antikolinesteraz \\ Aktivitesinin Belirlenmesi
}

\author{
(D) Ahmet EMIR*, (D) Ceren EMIR, (D) Buket BOZKURT, (D) Nehir ÜNVER SOMER \\ Ege University, Faculty of Pharmacy, Department of Pharmacognosy, Bornova, İzmir, Turkey
}

\begin{abstract}
Objectives: Amaryllidaceae alkaloids are well known for their wide range of pharmacological activities. Galanthamine, an Amaryllidaceae alkaloid, is an effective, selective, reversible, and competitive cholinesterase inhibitor marketed under different commercial names in several countries for the treatment of Alzheimer's disease. The aim of this work was to study the alkaloid profiles of the aerial parts and bulbs of both flowering and fruiting periods of Galanthus fosteri Baker (Amaryllidaceae), as well as analyzing their inhibitory activities on both acetylcholinesterase (AChE) and butyrylcholinesterase (BuChE) for the first time.

Materials and Methods: The alkaloid profiles of the four samples were determined by means of gas chromatography-mass spectrometry, and AChE and BuChE inhibition assays were performed by the modified Ellman method.

Results: Totally, 22 compounds with mass spectral characteristics of Amaryllidaceae alkaloids were detected in the extracts. Significant AChE and BuChE inhibitory activities were observed in the tested samples ( $\mathrm{IC}_{50}$ between 0.189 and $91.23 \mu \mathrm{g} / \mathrm{mL}$ ).

Conclusion: This study shows that G. fosteri, collected from Akdağ, Amasya (Turkey), is a potential source of diverse chemical structures of Amaryllidaceae alkaloids with cholinesterase inhibitory properties.
\end{abstract}

Key words: Galanthus fosteri, Amaryllidaceae alkaloids, anticholinesterase activity

\section{ÖZ}

Amaç: Amaryllidaceae alkaloitleri geniş yelpazedeki farmakolojik aktiviteleriyle iyi bilinmektedir. Bir Amaryllidaceae alkaloidi olan Galantamin, Alzheimer hastalığının tedavisi için çeșitli ülkelerde farklı ticari isimler altında pazarlanan etkili, seçici, geri dönüșümlü ve kompetitif kolinesteraz inhibitörüdür. Bu çalışma, ilk kez Galanthus fosteri Baker'in (Amaryllidaceae), hem çiçekli hem de meyveli dönemlerinin toprak üstü ve soğanlarının alkaloit profilini incelemenin yanı sıra hem asetilkolinesteraz (AChE) hem de butirilkolinesteraz (BuChE) üzerindeki inhibitör aktivitelerini analiz etmeyi amaçlamıştır.

Gereç ve Yöntemler: Dört örneğin alkaloit profilleri gaz kromatografisi-kütle spektrometrisi ile belirlendi ve AChE ve BuChE inhibisyon analizleri modifiye Ellman yöntemi ile yapılmıştır.

Bulgular: Ekstrelerde Amaryllidaceae alkaloitlerinin kütle spektral özellikleri olan toplam yirmi iki bileșik tespit edilmiștir. Test edilen örneklerde belirgin șekilde AChE ve BuChE inhibitör aktiviteler gözlenmiștir (IC50 0,189 ile 91,23 $\mathrm{fg} / \mathrm{mL}$ arasında).

Sonuç: Bu çalıșma, Amasya Akdağ'dan (Türkiye) toplanan G. fosteri'nin kolinesteraz inhibitör özelliğine sahip çeşitli kimyasal yapıdaki Amaryllidaceae alkaloitlerinin kaynağı olma potansiyeline sahip olduğunu göstermiștir.

Anahtar kelimeler: Galanthus fosteri, Amaryllidaceae alkaloitleri, antikolinesteraz aktivite

*Correspondence: E-mail: ahmet.emir@ege.edu.tr, Phone: +90 5053932109 ORCID-ID: orcid.org/0000-0002-0971-7716

Received: 09.07.2018, Accepted: 11.10.2018

๑Turk J Pharm Sci, Published by Galenos Publishing House. 


\section{INTRODUCTION}

Galanthus fosteri (G. fosteri) Baker (snowdrop) is a bulbous monocotyledon plant belonging to the family Amaryllidaceae occurring mainly in south- and north-central Turkey. Plants of this family are known to possess alkaloids with diverse chemical structures and a wide spectrum of biological activities such as cholinesterase inhibitory, antimalarial, hepatoprotective, antitumoral, anti-inflammatory, and antiviral..$^{2-7}$ Alzheimer's disease (AD), the most common cause of dementia and affecting approximately 46.8 million people worldwide, is a neurodegenerative disease characterized by widespread loss of central cholinergic function. ${ }^{8}$ The human central nervous system contains two cholinesterases: acetylcholinesterase (AChE), encoded by a gene on chromosome 7 , and butyrylcholinesterase (BuChE), encoded by a gene on chromosome 3. Although the role of $\mathrm{AChE}$ in the cholinergic system is well known, the role of BuChE is poorly understood. However, each enzyme alone is not sufficient for acetylcholine metabolism and cholinergic transmission. ${ }^{910}$ Therefore, in the treatment of $A D$, it is important to inhibit AChE as well as BuChE. Galanthamine, the most important alkaloid found in Amaryllidaceae plants, marketed under the commercial name of Reminy ${ }^{\circledR}$ in Europe and elsewhere and Razadine ${ }^{\circledR}$ in the USA, is used to treat $A D$ owing to its cholinesterase inhibitory properties."

It has been found that Amaryllidaceae alkaloids can be analyzed by gas chromatography-mass spectrometry (GC/MS) without any previous derivatization, and they show a mass spectral fragmentation pattern very similar to those recorded..$^{2}$ In the present study, the alkaloid profile of $G$. fosteri was determined by GC/MS, using both bulbs and aerial parts of the flowering and fruiting periods. In addition, cholinesterase inhibitory activity potentials of the extracts were examined spectrophotometrically using a microplate assay modified from Ellman's in vitro method with a 96-well micro-plate reader..$^{13,14}$

\section{MATERIALS AND METHODS}

\section{Plant material}

G. fosteri was collected from Akdağ, Amasya, on March 28, 2012 and April 1, 2013 during the flowering and fruiting periods, respectively. The plants were identified by Prof. M. Ali Onur from the Department of Pharmacognosy, Faculty of Pharmacy, Ege University, İzmir, Turkey. Voucher samples of G. fosteri (No: 1516, 1525) are deposited in the Herbarium of the Department of Pharmacognosy, Faculty of Pharmacy, Ege University.

\section{Alkaloid extraction}

The alkaloidal extracts were prepared from air-dried and powdered aerial parts and bulbs of $G$. fosteri Baker to be used in GC/MS analysis and in the anticholinesterase activity assay. Plant material $(500 \mathrm{mg}$ ) was separately extracted 3 times with methanol $(5 \mathrm{~mL})$ at room temperature. The solvent was evaporated under reduced pressure, the residues were dissolved in $10 \mathrm{~mL}$ of $2 \%$ sulfuric acid, and the neutral compounds were removed with diethyl ether $(3 \times 10 \mathrm{~mL})$. The acidic aqueous phases were basified with $25 \%$ ammonia to $\mathrm{pH}$
9-10 and the alkaloids were extracted with chloroform ( $3 \times 10$ $\mathrm{mL}$ ). The combined chloroform extracts were then dried over anhydrous sodium sulfate, filtered, and the organic solvent was distilled in vacuo to afford the alkaloidal extract. ${ }^{15}$ The obtained extracts were used for GC/MS analysis and also screened for anticholinesterase activity.

\section{GC/MS analysis}

The GC/MS analysis was performed using Thermo GC-Trace Ultra Ver: 2.0., Thermo MS DSQ II (Thermo Fisher Scientific, San Jose, CA, USA) operating in electron impact mode (EI, 70 $\mathrm{eV})$. The oven temperature was programmed as $80^{\circ} \mathrm{C}$ for $1 \mathrm{~min}$, $80-250^{\circ} \mathrm{C}\left(10^{\circ} \mathrm{C} \mathrm{min}^{-1}\right), 250^{\circ} \mathrm{C}$ for $2 \mathrm{~min}, 250-300^{\circ} \mathrm{C}\left(10^{\circ} \mathrm{C} \mathrm{min}\right.$ 1), and a $10 \mathrm{~min}$ hold at $300^{\circ} \mathrm{C}$. The injector temperature was $250^{\circ} \mathrm{C}$. Helium was used as carrier gas at a flow rate of 0.8 $\mathrm{mL} \mathrm{min}{ }^{-1}$. A TR-5 MS column ( $30 \mathrm{~m} \times 0.25 \mathrm{~mm} \times 0.25 \mu \mathrm{m}$ ) was used. The extracts were dissolved in methanol $(1 \mathrm{mg}$ of extract in $500 \mu \mathrm{L}$ of methanol). All injections were run in splitless mode. The spectra of co-eluting chromatographic peaks were investigated and deconvoluted by the use of Xcalibur (version 2.07; Thermo Fisher Scientific San Jose, CA, USA). The compounds were identified by comparing their mass spectral fragmentation with standard reference spectra from the NIST 05 database (NIST Mass Spectral Database, PC-Version 5.0 (2005), National Institute of Standardization and Technology, Gaithersburg, MD, USA), or applying co-chromatography with previously isolated authentic standards and in comparison with data obtained from the literature. The percentage of total ion current for each compound is given in Table 1. The area of the GC/MS peaks depends both on the concentration of the corresponding compound and on the intensity of their mass spectral fragmentation. Moreover, they can be used for a relative comparison of alkaloids.

\section{Anticholinesterase activity}

The alkaloidal extracts of the aerial parts and bulbs were tested for their AChE and BuChE inhibitory activities by 96well microplate assay modified from Ellman's method at the concentration range of $0.006-600 \mu \mathrm{g} / \mathrm{mL}$ (final concentrations in the assay $0.0015-150 \mu \mathrm{g} / \mathrm{mL}$ ). ${ }^{13,14}$ Galanthamine was used as a positive control. The enzyme inhibitory activity was calculated as the percentage compared to the blank. $I C_{50}$ values were analyzed by the software package Prism V5.0 (GraphPad Inc., San Diego, CA, USA).

\section{RESULTS}

A great number of alkaloids present in Amaryllidaceous plant extracts have been separated effectively and identified very quickly by $\mathrm{GC} / \mathrm{MS}$, indicating that this method for chemical analysis is useful and reliable for studies on the alkaloid metabolism in this family.2.16 To the best of our knowledge, this is the first report of a GC/MS study on the alkaloids of G. fosteri growing in Turkey. The alkaloid patterns of the samples were normalized and presented as a \% of individual compounds in the total alkaloidal mixture based on the deconvoluted peak area (Table 1). The structures of the alkaloids are given in Figure 1. Totally, 22 compounds with mass spectral characteristics 
Table 1. GC/MS data and relative composition of the alkaloids in the extracts of G. fosteri

\begin{tabular}{|c|c|c|c|c|c|c|c|c|}
\hline \multirow{3}{*}{ Compound } & \multirow{3}{*}{$\begin{array}{l}\text { R.T. } \\
(\min )\end{array}$} & \multirow{3}{*}[\mathrm{M}^{+}]{} & \multirow{3}{*}{ m/z (relative intensity, \%) } & \multicolumn{4}{|c|}{ Content (percentage of $\mathrm{TIC}$ ) } & \multirow{3}{*}{ References } \\
\hline & & & & \multicolumn{2}{|c|}{$\begin{array}{l}\text { Flowering } \\
\text { period }\end{array}$} & \multicolumn{2}{|c|}{ Fruiting period } & \\
\hline & & & & $\begin{array}{l}\text { Aerial } \\
\text { parts }\end{array}$ & Bulbs & $\begin{array}{l}\text { Aerial } \\
\text { parts }\end{array}$ & Bulbs & \\
\hline Hordenine ${ }^{(a)}(1)$ & 11.2 & $165(1)$ & $121(2), 107(4), 91(3), 77(7), 58(100)$ & 1.86 & 7.40 & 6.08 & 5.85 & 17 \\
\hline$M^{+} 255^{(a)}(2)$ & 16.91 & $255(22)$ & $\begin{array}{l}240(42), 181(100) 153(37), 152 \\
(47), 97(27), 73(51)\end{array}$ & - & - & - & 0.11 & 18 \\
\hline Ismine ${ }^{(b)}(3)$ & 20.13 & $257(29)$ & $238(100), 211(6), 196(11), 168(8)$ & 0.16 & 0.22 & $t$ & 1.35 & 19 \\
\hline Trisphaeridine $e^{(b)}(4)$ & 21.05 & $223(100)$ & $\begin{array}{l}222(38), 167(11), 138 \text { (27), } 111(19), \\
69(21)\end{array}$ & - & 0.35 & $t$ & 1.18 & 19 \\
\hline 5,6-Dihydrobicolorine $($ b) $(5)$ & 21.05 & $239(36)$ & $\begin{array}{l}238(100), 180(15), 129(65), 113 \\
(18), 112(25), 111(27), 71(37)\end{array}$ & $t$ & - & 0.16 & 1.51 & 15 \\
\hline Crinine ${ }^{(c)}(6)$ & 21.40 & $271(100)$ & $\begin{array}{l}270(35), 254(5), 228(37), 214(10), \\
199(26), 185(31), 150(51), 122(54)\end{array}$ & 0.13 & 0.27 & 0.16 & - & 20 \\
\hline Galanthamine $^{(\mathrm{d})}(7)$ & 21.60 & $287(80)$ & $\begin{array}{l}286(100), 270(14), 244 \text { (39), } 230 \\
(19), 216(38)\end{array}$ & 0.21 & 0.94 & 3.18 & 0.33 & S, NIST 05 \\
\hline Galanthindole ${ }^{(e)}(8)$ & 22.74 & $281(100)$ & $\begin{array}{l}262(23), 207(26), 191(30), 149 \\
(20), 97(21), 73(26)\end{array}$ & - & - & - & 0.33 & 21 \\
\hline 9-O-Demethylmaritidine ${ }^{(f)}(9)$ & 22.84 & $273(81)$ & $\begin{array}{l}202 \text { (29), } 201(100), 189(71), 175 \\
(28), 115(27)\end{array}$ & - & 9.07 & - & 2.62 & 22 \\
\hline Anhydrolycorine ${ }^{(g)}(10)$ & 22.98 & $251(41)$ & $\begin{array}{l}250(100), 224(17), 192(16), 191 \\
(14), 96(11)\end{array}$ & - & - & - & 1.24 & 23 \\
\hline O,N-dimethylnorbelladine ${ }^{(\mathrm{h})}(11)$ & 23.22 & $303(9)$ & $\begin{array}{l}180(29), 137(100), 122(6), 94(5), \\
77(7)\end{array}$ & 1.48 & 2.37 & 1.04 & 1.36 & 24 \\
\hline Assoanine $^{(\mathrm{g})}(12)$ & 23.56 & $267(52)$ & $\begin{array}{l}266(100), 250(31), 222(14), 207 \\
(14), 193(12), 180(15)\end{array}$ & $t$ & - & - & 0.72 & 15 \\
\hline $\begin{array}{l}\text { 11,12-Didehydroanhydrolycorine }{ }^{(g)} \\
(13)\end{array}$ & 24.03 & $249(57)$ & $\begin{array}{l}248 \text { (100), } 207(10), 191(16) 190 \\
(30), 95 \text { (23), }\end{array}$ & - & 0.67 & - & 0.96 & 25,26 \\
\hline Galanthine $e^{(g)}(14)$ & 24.54 & $317(15)$ & $\begin{array}{l}316(11), 284(10), 268(16), 266 \\
(10), 244(16), 243(92), 242(100)\end{array}$ & 0.36 & 3.08 & 0.33 & 1.08 & 19 \\
\hline 11-Hydroxyvittatine ${ }^{(f)}(15)$ & 24.89 & $287(9)$ & $\begin{array}{l}258(100), 242(12), 211(15), 186 \\
(20), 181(20), 153(10), 115(17)\end{array}$ & - & 8.37 & 2.38 & 13.51 & $\mathrm{~S},{ }^{19}$ \\
\hline Incartine $e^{(\mathrm{g})}(16)$ & 25.10 & $333(30)$ & $332(77), 259(72), 258(100), 244(18)$ & 24.88 & 40.03 & 22.21 & 32.70 & $S,{ }^{17}$ \\
\hline Lycorine $e^{(g)}(17)$ & 25.28 & 287 (19) & $\begin{array}{l}268(17), 250(14), 228(11), 227 \\
(67), 226(100), 147(12)\end{array}$ & - & 5.39 & - & 0.97 & 23 \\
\hline 9-O-methylpseudolycorine $\mathrm{g}^{(\mathrm{g})}(18)$ & 25.36 & $303(18)$ & $\begin{array}{l}302(16), 284 \text { (16), } 243 \text { (72), } 242 \text { (100), } \\
240 \text { (11), } 227 \text { (21), } 226 \text { (30), } 207 \text { (34) }\end{array}$ & - & 1.34 & - & 0.99 & $\mathrm{~S},{ }^{24}$ \\
\hline $\begin{array}{l}\text { 11-O-acetyl-9-O- } \\
\text { demethylmaritidine }{ }^{(f)}(19)\end{array}$ & 25.8 & $331(100)$ & $\begin{array}{l}272(54), 271(86), 254(51), 242 \\
(58), 226(74), 181(66), 115(47)\end{array}$ & 64.51 & 12.57 & 62.79 & 9.12 & $\mathrm{~S},{ }^{24}$ \\
\hline $\begin{array}{l}\text { 3,11-O-diacetyl-9-O- } \\
\text { demethylmaritidine }{ }^{(f)}(20)\end{array}$ & 26.28 & $373(42)$ & $\begin{array}{l}254 \text { (38), } 242(48), 229(69), 227 \\
(66), 226(98), 211(90), 181(100)\end{array}$ & 5.25 & - & 3.22 & - & $S,{ }^{24}$ \\
\hline Galwesine $^{(i)}(21)$ & 26.78 & $361(12)$ & $\begin{array}{l}207(43), 155(88), 140(100), 112 \\
(20), 96(16), 73(20)\end{array}$ & 0.21 & - & - & - & 20 \\
\hline Oxoincartine ${ }^{(g)}(22)$ & 29.52 & $347(40)$ & 273 (100), 258 (68), 207 (42), 73 (16) & 0.32 & 1.54 & 0.43 & 2.70 & $S,{ }^{24}$ \\
\hline
\end{tabular}

a: Other, b: Phenanthridine, c: Crinine, d: Galanthamine, e: Indole, f: Haemanthamine, s: Lycorine, h: Norbelladine, i: Homolycorine, t: Trace <0.1, S: Standard, TIC: Total ionic concentration, G. fosteri: Galanthus fosteri 
<smiles>CN(C)CCc1ccc(O)cc1</smiles>

3<smiles>Nc1ccccc1-c1cc2c(cc1CO)OCO2</smiles>

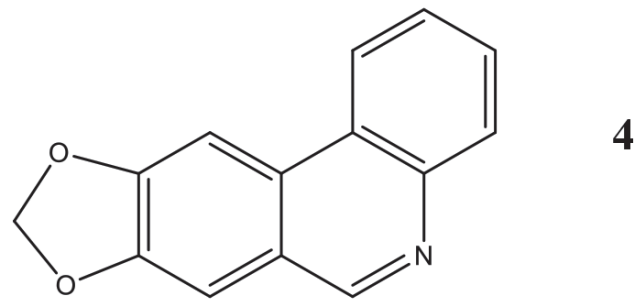

1<smiles>CN1Cc2cc3c(cc2-c2ccccc21)OCO3</smiles>

5

6
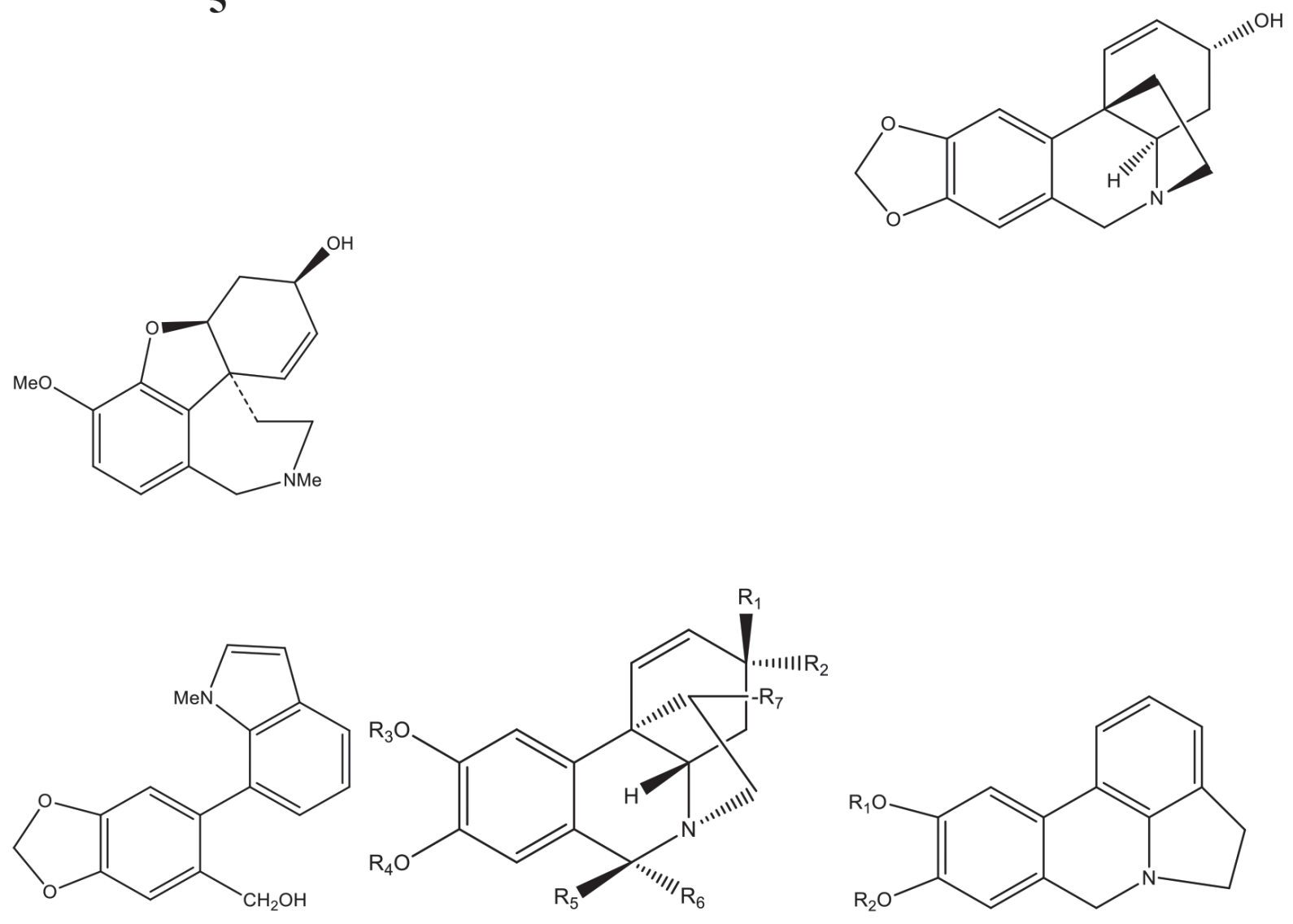


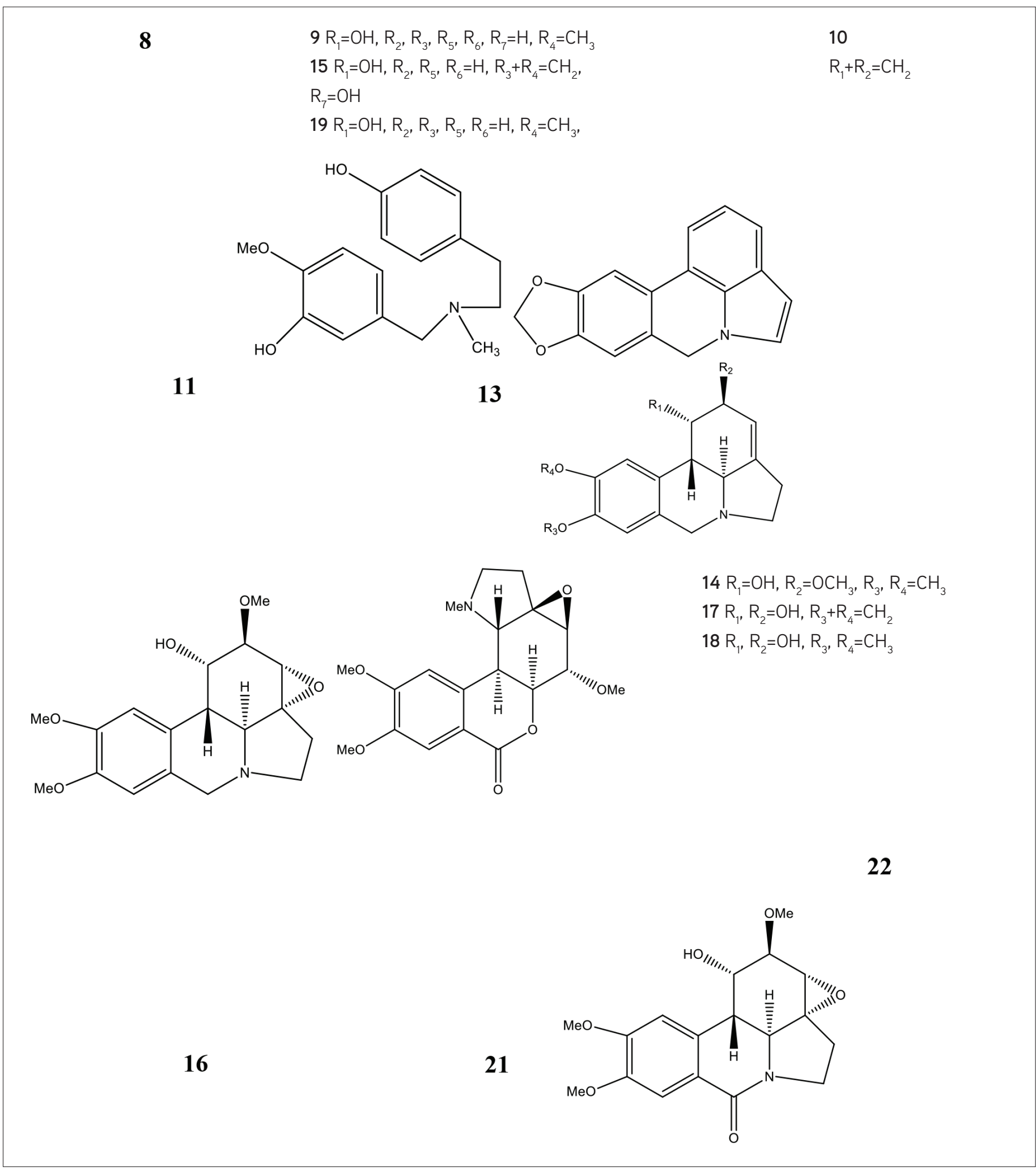

Figure 1. Structures of alkaloids identified in Galanthus fosteri: hordenine (1), ismine (3), trisphaeridine (4), 5,6-dihydrobicolorine (5), crinine (6), galanthamine (7), galanthindole (8), 9-O-demethylmaritidine (9), anhydrolycorine (10), O,N-dimethylnorbelladine (11), assoanine (12), 11,12-didehydroanhydrolycorine (13), galanthine (14), 11-hydroxyvittatine (15), incartine (16), lycorine (17), 9-O-methylpseudolycorine (18), 11-O-acetyl-9-Odemethylmaritidine (19), 3,11-O-diacetyl9-O-demethylmaritidine (20), galwesine (21), oxoincartine (22)

of Amaryllidaceae alkaloids were detected in the extracts of the aerial parts and bulbs of both the flowering and fruiting periods (Table 1). The identified compounds possessed various Amaryllidaceae alkaloid skeleton types including lycorine, 
haemanthamine, narciclasine, homolycorine, norbelladine, galanthamine, and crinine types and additionally indole alkaloid and another base hordenine. Hordenine is not typical for plants of the family Amaryllidaceae. It has been found mainly in other plant families like Poaceae (Hordeum vulgare), Cactaceae (in a very wide range of species), and in a few algae and fungi. ${ }^{20}$ In addition, one compound showing mass spectral fragmentation characteristic of Amaryllidaceae alkaloids was left unidentified due to lack of reference MS spectra. Of the 22 alkaloids identified, only seven, hordenine, galanthamine, $\mathrm{O}, \mathrm{N}$-dimethylnorbelladine, galanthine, incartine, 11-O-acetyl9-O-demethylmaritidine, and oxoincartine, were common in all the samples. The results obtained from the microplate assay for cholinesterase inhibitory activity of the samples ranged between $0.189 \mu \mathrm{g} / \mathrm{mL}$ and $91.23 \mu \mathrm{g} / \mathrm{mL} ; I_{50}$ values $(\mu \mathrm{g} / \mathrm{mL})$ are shown in Table 2.

Table 2. Cholinesterase inhibitory activity of extracts

\begin{tabular}{|c|c|c|c|}
\hline Sample & & $\begin{array}{l}\text { AChE [IC } \\
(\mu \mathrm{g} / \mathrm{mL})]\end{array}$ & BuChE $\left[\mathrm{IC}_{50}(\mu \mathrm{g} / \mathrm{mL})\right]$ \\
\hline \multirow{2}{*}{$\begin{array}{l}\text { Flowering } \\
\text { period }\end{array}$} & $\begin{array}{l}\text { Aerial } \\
\text { parts }\end{array}$ & 13.15 & 91.23 \\
\hline & Bulbs & 8.63 & 37.125 \\
\hline \multirow{2}{*}{$\begin{array}{l}\text { Fruiting } \\
\text { period }\end{array}$} & $\begin{array}{l}\text { Aerial } \\
\text { parts }\end{array}$ & 0.189 & 21.98 \\
\hline & Bulbs & 7.12 & 20.65 \\
\hline Galanthamine & & 0.043 & 0.711 \\
\hline
\end{tabular}

\section{CONCLUSION}

The findings of the present study demonstrate the potential of $G$. fosteri collected in north-central Turkey as a source of cholinesterase inhibitor compounds with diverse chemical structures of Amaryllidaceae alkaloids. The alkaloidal patterns of the aerial parts and bulbs were dominated by 11-O-acetyl-9O-demethylmaritidine, which has remarkable AChE and BuChE inhibitory activities with $\mathrm{IC}_{50}$ values of $6.04 \mu \mathrm{M}$ and $29.72 \mu \mathrm{M}$, respectively. Furthermore, incartine is the main alkaloid in bulbs and it has shown low anticholinesterase activity. ${ }^{24}$ The number of alkaloids in the bulbs was considerably higher in comparison with the aerial parts. Generally, lycorine and haemanthamine type alkaloids were the major components in the tested samples. Thus, the products of ortho-para' and parapara' oxidative phenolic coupling dominate in samples. Both groups of alkaloids have quite pronounced biological activities. Lycorine type alkaloids have antitumor, antiviral, antibacterial, antifungal, anticholinesterase, and analgesic activities, while haemanthamine type alkaloids have antitumor, antimalarial, antibacterial, analgesic, and anti-inflammatory activities. ${ }^{27-30}$ The highest anticholinesterase activity was shown in the aerial parts of the fruiting period, which have the highest relative amount of galantamine. Moreover, the highest BuChE inhibitory activity was detected in the bulbs of the same period, which have the highest number of lycorine type alkaloids. Compared to the other Galanthus species ${ }^{31,32}$ in which both activities were examined, the aerial parts of the fruiting period stand out with their high AChE inhibitor activity, while BuChE inhibitor activity has similar values. In conclusion, the present study clearly suggests that GC/MS is an appropriate method for the rapid analysis of the qualitative and relative amounts of alkaloid composition in G. fosteri specimens, which have diverse alkaloid structures and anticholinesterase activity.

\section{ACKNOWLEDGEMENTS}

We thank the Pharmaceutical Science Research Centre (FABAL) and Ege University Research Fund (2014/ECZ/20) for their financial support.

Conflicts of interest: No conflict of interest was declared by the authors.

\section{REFERENCES}

1. Davis AP. The genus Galanthus-snowdrops in the wild. In: Snowdrops, A Monograph of Cultivated Galanthus. Cheltenham; Griffin Press Publishing Ltd. 2006:9-63.

2. McNulty J, Nair JJ, Little JR, Brennan D, Bastida J. Structure-activity studies on acetylcholinesterase inhibition in the lycorine series of Amaryllidaceae alkaloids. Bioorg Med Chem Lett. 2010;20:5290-5294.

3. Cedrón JC, Gitiérrez D, Flores N, Ravelo ÁG, Estévez-Braun A. Synthesis and antimalarial activity of new haemanthamine-type derivatives. Bioorg Med Chem. 2012;20:5464-5472.

4. Ilavenil S, Kaleeswaran B, Ravikumar S. Protective effects of lycorine against carbon tetrachloride induced hepatotoxicity in Swiss albino mice. Fundam Clin Pharmacol. 2012;26:393-401.

5. Dalecká M, Havelek R, Královec K, Brucková L, Cahlíková L. Amaryllidaceae family alkaloids as potential drugs for cancer treatment. Chem Listy. 2013;107:701-708.

6. Çitoğlu G, Tanker M, Gümüșel B. Antiinflammatory effects of lycorine and haemanthidine. Phytother Res. 1988;12:205-206.

7. He J, Qi WB, Wang L, Tian J, Jiao PR, Liu GQ, Ye WC, Liao M. Amaryllidaceae alkaloids inhibit nuclear-to-cytoplasmic export of ribonucleoprotein (RNP) complex of highly pathogenic avian influenza virus H5N1. Influenza Other Respir Viruses. 2012;7:922-931.

8. Cummings J, Aisen PS, DuBois B, Frölich L, Jack CR Jr, Jones RW, Morris JC, Raskin J, Dowsett SA, Scheltens P. Drug development in Alzheimer's disease: the path to 2025. Alzheimers Res Ther. 2016:8;39.

9. Xie W, Stribley JA, Chatonnet A, Wilder PJ, Rizzino A, Mccomb RD, Taylor P, Hinrichs SH, Lockridgeet O. Postnatal developmental delay and supersensitivity to organophosphate in gene-targeted mice lacking acetylcholinesterase. J Pharmacol Exp Ther. 2000;293:896-902.

10. Mesulam M, Gullozet A, Shaw P, Levey A, Duysen EG, Lockridge O. Acetylcholinesterase knockouts establish central cholinergıc pathways and can use butyrylcholinesterase to hydrolyze acetylcholine. Neuroscience. 2002;110:627-639.

11. Torras-Claveria L, Berkov S, Codina C, Viladomat F, Bastida J. Daffodils as potential crops of galanthamine. Assessment of more than 100 ornamental varieties for their alkaloid content and acetylcholinesterase inhibitory activity. Ind Crops Prod. 2013;43:237-244. 
12. Kreh M, Matusch R, Witte L. Capillary gas chromatography-mass spectrometry of Amaryllidaceae alkaloids. Phytochemistry. 1995;38:773-776.

13. Ellman L, Courtney KD, Andres V Jr, Feather-Stone RM. New and rapid colorimetric determination of acetylcholinesterase activity. Biochem Pharmacol. 1961;7:88-95.

14. López S, Bastida J, Viladomat F, Codina C. Acetylcholinesterase inhibitory activity of some Amaryllidaceae alkaloids and Narcissus extracts. Life Sci. 2002;71:2521-2529.

15. Bozkurt B, Emir A, Kaya GI, Önür MA, Berkov S, Bastida J, Somer NÜ. Alkaloid profiling of Galanthus woronowii Losinsk. by GC-MS and evaluation of its biological activity. Marmara Pharmaceutical Journal. 2017;21:915-920.

16. Berkov S, Pavlov A, llieva M, Burrus M, Popov S. Stanilova M. CGCMS of alkaloids in Leucojum aestivum plants and their in vitro cultures. Phytochem Anal. 2005;16:98-103.

17. Berkov S, Bastida J, Sidjimova B, Francesc V, Codina C. Phytochemical differentiation of Galanthus nivalis and Galanthus elwesii (Amaryllidaceae): A case study. Biochem Syst Ecol. 2008;36:638-645.

18. Cortes N, Alvarez R, Osorio EH, Alzate F, Berkov S, Osorio E. Alkaloid metabolite profiles by GC/MS and acetylcholinesterase inhibitory activities with binding-mode predictions of five Amaryllidaceae plants. J Pharm Biomed Anal. 2015;102:222-228.

19. Torras-Claveria L, Berkov S, Jáuregui O, Caujapé J, Viladomat F, Codina C, Bastida J. Metabolic Profiling of bioactive Pancratium canariense extracts by GC-MS. Phytochem Anal. 2010;21:80-88.

20. Berkov S, Romani S, Herrera M, Viladomat F, Codina C, Momekov G, Ionkova I, Bastida J. Antiproliferative alkaloids from Crinum zeylanicum. Phytother Res. 2011;25:1686-1692.

21. de Andrade JP, Pigni NB, Torras-Claveria L, Berkov S, Codina C, Viladomat F, Bastida J. Bioactive alkaloid extracts from Narcissus broussonetii: Mass spectral studies. J Pharm Biomed. 2012;70:13-25.

22. Bastida J, Llabrés JM, Viladomat F, Codina C, Rubiralta M, Feliz M. 9-0-Demethylmaritidine: A New Alkaloid from Narcissus radinganorum. Planta Med. 1988;54:524-526.

23. Berkov S, Evstatieva L, Popov S. Alkaloids in Bulgarian Pancratium maritimum L. Z Naturforsch C J Biosci. 2004;59:65-69.

24. Emir A, Emir C, Bozkurt B, Onur MA, Bastida J, Somer NU. Alkaloids from Galanthus fosteri. Phytochem Lett. 2016;17:167-172.

25. Berkov S, Bastida J, Tsvetkova R, Viladomat F, Codina C. Alkaloids from Sternbergia colchiciflora. Z Naturforsch C J Biosci 2009;64:311-316.

26. Berkov S, Bastida J, Sidjimova B, Viladomat F, Codina C. Alkaloid diversity in Galanthus elwesii and Galanthus nivalis. Chem Biodivers. 2011;8;115-130.

27. Bastida J, Berkov S, Torras L, Pigni NB, de Andrade JP, Martínez V. Codina C, Viladomat F. Chemical and biological aspects of Amaryllidaceae alkaloids. Transworld Research Network. 2011:65-100.

28. Cedrón JC, Arco-Aguilar MD, Estévez-Braun A, Ravelo AG. Chemistry and Biology of Pancratium Alkaloids. 2010;68:1-37.

29. Ding Y, Qu D, Zhang KM, Cang XX, Kou ZN, Xiao W, Zhu JB. Phytochemical and biological investigations of Amaryllidaceae alkaloids: a review. $J$ Asian Nat Prod Res. 2016;19;53-100.

30. He M, Qu C, Gao O, Hu X, Hong X. Biological and pharmacological activities of amaryllidaceae alkaloids. RSC Adv. 2015;5:16562-16574.

31. Kaya Gl, Uzun K, Bozkurt B, Onur MA, Somer NU, Glatzel DK, Fürst R. Chemical characterization and biological activity of an endemic Amaryllidaceae species: Galanthus cilicicus. S Afr J Bot. 2017;108:256260.

32. Bozkurt B, Coban G, Kaya Gl, Onur MA, Unver-Somer N. Alkaloid profiling, anticholinesterase activity and molecular modeling study of Galanthus elwesii. S Afr J Bot. 2017;113;119-127. 